\title{
US expected to exempt most recombinant DNA experiments from federal regulation
}

\author{
Eighty-five per cent of US recombinant DNA experiments will be exempted from controls, \\ if the recommendations of a national committee are accepted. David Dickson reports
}

A large proportion of current experiments using recombinant DNA techniques is expected to become exempt from federal regulations covering such research, following a recommendation which a national advisory committee agreed last week to make to the director of the National Institutes of Health.

In a split decision, the NIH's recombinant DNA Advisory Committee agreed that all experiments using the 'disabled' K12 strain of the bacterium Escherichia coli be exempted from the guidelines, except for those which are known to present a particular type of hazard.

The decision has been taken after pressure from scientists, many of whom have argued that the results of recent research fail to support earlier speculations over the hazards of recombinant DNA research. Critics, however, still argue that such a decision is premature, and that there is inadequate knowledge of the risks involved to justify taking such a significant step at this stage.

In its recommendation, the RAC suggests that the experiments exempted from the guidelines should still be carried out under P1 containment conditions, the lowest of four levels of physical containment established in the guidelines which were first published by the NIH in 1976. It also recommends that the experiments should be notified to local institutional biohazard committees, which all institutions carrying out recombinant DNA research on federal funds are required to set up.

However under the committee's recommendations, which are expected to be accepted with little alteration by $\mathrm{Dr}$ Donald Fredrickson, director of NIH, there will be no need to obtain prior approval for the experiments from the local committee. Nor will it be necessary to inform the NIH's own Office of Recombinant DNA Activities (ORDA), as all research workers are required to do at present.

Members of the advisory committee voted by ten votes to four, with one abstention, in favour of the exemptions. In general, the scientific members of the committee, many of whom are actively involved in recombinant DNA research or related fields, voted in favour of the exemptions - while those appointed as 'public interest' representatives on the committee voted against them.

During the debate on the proposal, it was said that about $85 \%$ of current recombinant DNA experiments were conducted using the $E$. coli $\mathrm{K} 12$ strain. The proposed exemptions would not apply to experiments currently prohibited under the guidelines, such as those involving the transfer of genetic material from known toxins, or to experiments involving more than 10 litres of culture - for which special permission is required.

Some members of the committee argued that no decision should taken before the committee had had time to examine the implications of the risk assessment scheme which has been developed by Dr Sidney Brenner of the Medical Research Council laboratory in Cambridge, England. This approach is now being used as a basis for decision-making by Britain's Genetic Manipulation Advisory Group. However other committee members argued that Dr Brenner's concerns were adequately covered by the NIH guidelines. And it was also decided that it was not necessary to wait until Dr Brenner could appear personally before the committee before recommending exemption for the $E$. coli $\mathrm{K} 12$ experiments.

During the committee's two-day meeting in Bethesda, approval was given to a set of procedures which have been drawn up by the director of NIH under which private companies can voluntarily register their experiments with ORDA.

Dr Fredrickson told the committee that he was confident that commercially sensitive information could be adequately protected, a factor that had previously

\section{US to harmonise remote sensing}

The United States has agreed to initiate efforts to "harmonise and rationalise" international activities in the field of remote sensing - the mapping of natural resources from satellites. Such efforts should, according to the US, have two main goals: ensuring the compatibility between the remote sensing systems now being developed by different industrialised countries, and stimulating the full use of remote sensing data by the developing countries.

The decision to take this initiative was announced during the first week of the United Nations Conference on Science and Technology for Development held in Vienna last month, by Father Theodore Hesburgh, head of the US delegation to UNCSTD. Addressing the plenary session of the conference, Father Hesburgh said that the US proposed bringing together the operators of remote sensing satellites, as well as the users, to develop an international system.

"We believe that satellites should he made companies reluctant to divulge details of their proposed experiments. He also said that before leaving the Department of Health, Education and Welfare, ex-secretary Mr Joseph Califano had indicated that he was opposed to new legislation covering the private sector.

In a subsequent closed session, the committee gave its approval to large-scale experiments involving more than ten litres of culture submitted by the pharmaceutical company Eli Lilly and the west coast research company Genentech. The two companies are currently collaborating on efforts to produce sufficient quantities of human insulin to begin clinical trials.

The committee also agreed on a set of procedures, based on proposals of a small working group, on how it should conduct its business. Against the advice of the NIH's legal counsel, Mr Richard Riseberg, the committee decided that members having a 'personal stake' in the outcome of a particular line of research should not necessarily be excluded from discussions realted to that research.

$\mathrm{Mr}$ Riseberg informed the committee that it might be contravening federal law if, as an advisory committee, members took part in such discussions. Some committee members, however, pointed to the difficulty of determining what 'personal stake' meant in the context of scientific research - and the committee decided to strike out the provision.

operated so that all can have easy access to the data and so that information can be collected without unnecessary duplication and for maximum mutual benefit", Father Hesburgh said.

"The objective is to ensure developing countries improve their access to information for the use and management of forests, rangelands, water supplies, soil preservation, and the indentifiction of new mineral and water resources."

The Administration has been under pressure from Congress for some time to decide what steps to take following the experience gained with the series of Landsat experimental satellites. Landsat A was launched in 1972, and operated successfully for five years, and its successor Landsat B was launched in 1976. The last of four satellites, Landsat $D$, is due to be launched in 1981.

Despite the exceptionally high quality of the Landsat images, analysis of them had had mixed success. In some areas, such as the survey of water or mineral resources, 